\title{
Relating particle hygroscopicity and CCN activity to chemical composition during the HCCT-2010 field campaign
}

\author{
Z. J. Wu, L. Poulain, S. Henning, K. Dieckmann, W. Birmili, M. Merkel, D. van Pinxteren, G. Spindler, K. Müller, \\ F. Stratmann, H. Herrmann, and A. Wiedensohler \\ Leibniz Institute for Tropospheric Research, Permoserstraße 15, 04318 Leipzig, Leipzig, Germany
}

Correspondence to: Z. J.Wu (wuzhijun@tropos.de)

Received: 22 February 2013 - Published in Atmos. Chem. Phys. Discuss.: 20 March 2013

Revised: 15 June 2013 - Accepted: 16 July 2013 - Published: 19 August 2013

\begin{abstract}
Particle hygroscopic growth at $90 \%$ RH (relative humidity), cloud condensation nuclei $(\mathrm{CCN})$ activity, and size-resolved chemical composition were concurrently measured in the Thüringer Wald mid-level mountain range in central Germany in the fall of 2010. The median hygroscopicity parameter values, $\kappa$, of 50,75 , $100,150,200$, and $250 \mathrm{~nm}$ particles derived from hygroscopicity measurements are respectively $0.14,0.14,0.17$, $0.21,0.24$, and 0.28 during the sampling period. The closure between HTDMA (Hygroscopicity Tandem Differential Mobility Analyzers)-measured ( $\left.\kappa_{\mathrm{HTDMA}}\right)$ and chemical composition-derived $\left(\kappa_{\text {chem }}\right)$ hygroscopicity parameters was performed based on the Zdanovskii-Stokes-Robinson (ZSR) mixing rule. Using size-averaged chemical composition, the $\kappa$ values are substantially overpredicted (30 and $40 \%$ for 150 and $100 \mathrm{~nm}$ particles). Introducing size-resolved chemical composition substantially improved closure. We found that the evaporation of $\mathrm{NH}_{4} \mathrm{NO}_{3}$, which may happen in a HTDMA system, could lead to a discrepancy in predicted and measured particle hygroscopic growth. The hygroscopic parameter of the organic fraction, $\kappa_{\text {org }}$, is positively correlated with the $\mathrm{O}: \mathrm{C}$ ratio $\left(\kappa_{\mathrm{org}}=0.19 \times(\mathrm{O}: \mathrm{C})-0.03\right)$. Such correlation is helpful to define the $\kappa_{\text {org }}$ value in the closure study. $\kappa$ derived from CCN measurement was around $30 \%$ (varied with particle diameters) higher than that determined from particle hygroscopic growth measurements (here, hydrophilic mode is considered only). This difference might be explained by the surface tension effects, solution nonideality, gas-particle partitioning of semivolatile compounds, and the partial solubility of constituents or non-dissolved particle matter. Therefore, extrapolating from HTDMA data to properties at the point of activation should be done with great
\end{abstract}

care. Finally, closure study between $\mathrm{CCNc}$ (cloud condensation nucleus counter)-measured $\left(\kappa_{\mathrm{CCN}}\right)$ and chemical composition $\left(\kappa_{\mathrm{CCN}}\right.$,chem $)$ was performed using $\mathrm{CCNc}$-derived $\kappa$ values for individual components. The results show that the $\kappa_{\mathrm{CCN}}$ can be well predicted using particle size-resolved chemical composition and the ZSR mixing rule.

\section{Introduction}

The hygroscopic growth and the mixing state of aerosol particles play an important role for several atmospheric effects such as the direct aerosol effect on climate, visibility degradation, and cloud formation (Pandis et al., 1995; Sloane and Wolff, 1985; McFiggans et al., 2006). Through the interaction of atmospheric particles and cloud droplets with incoming shortwave radiation, the particle hygroscopic growth is one of the key parameters influencing the terrestrial radiation budget and, thus, climate (IPCC, 2007). Some uncertainties relate to the prediction of hygroscopic growth and $\mathrm{CCN}$ (cloud condensation nuclei) activation for the complex chemical mixtures of aerosol particles found in the atmosphere. Other uncertainties concern the way that hygroscopic growth and $\mathrm{CCN}$ activation can be parameterized for implementation in higher-scale climate models. To further elucidate physicochemical processes underlying the hygroscopic growth and the $\mathrm{CCN}$ activation, comprehensive field studies are required measuring multiple parameters of the atmospheric aerosol.

It has been a general approach to simulate hygroscopic particle growth on the basis of known hygroscopic growth factors of certain pure chemical species while assuming the ideal ZSR (Zdanovskii-Stokes-Robinson) mixing rule 
(Stokes and Robinson, 1966; Zdanovskii, 1948). The ZSR rule implies that the water uptake of internally mixed particles can be described as the sum of the volumetric water uptakes of the individual chemical fractions. The ZSR rule has proved to be appropriate when comparing to the directly measured growth factors of several atmospheric aerosols (e.g., Cubison et al., 2008; Irwin et al., 2011; Petters et al., 2009a). Early hygroscopic closure studies (e.g., Saxena et al., 1995; Swietlicki et al., 1999; Dick et al., 2000) had to rely on chemical composition obtained from aerodynamic impactor data, which are clearly limited in particle size and time resolution. These studies were therefore usually not able to capture the highly variable changes of chemical particle composition with time and their effects on hygroscopic growth and $\mathrm{CCN}$ activation.

Recently, aerosol mass spectrometers (AMS) have been increasingly deployed in atmospheric aerosol studies. They can provide a size-resolved chemical composition of nonrefractory particle material with high sensitivity with a time resolution of a few minutes (DeCarlo et al., 2006). Recent hygroscopic closure studies (Gysel et al., 2007; Lance et al., 2009; Cerully et al., 2011; Medina et al., 2007; Aklilu et al., 2006) confirmed the suitability of the ZSR mixing rule in conjunction with AMS data when predicting the hygroscopic growth of atmospheric aerosol particles. Some studies highlighted the advantage of using size-selective AMS information over size-averaged information from offline chemical characterization (Medina et al., 2007; Gunthe et al., 2009; Cerully et al., 2011).

Another key product of AMS measurements is the detailed information on organic molecular fragments. Unlike inorganic species that exhibit a well characterized hygroscopic growth, knowledge on the influence of water uptake of the organic aerosol fraction remains limited (Kanakidou et al., 2005; Zhang et al., 2007; Hallquist et al., 2009). This is in sharp contrast to the mass fraction of the organic aerosol, usually amounting to $20-90 \%$ in the fine particle mode (Zhang et al., 2007).

The water uptake of organic aerosols varies with its oxidation state (Jimenez et al., 2009), which may be highly variable in the real atmosphere, and depend on the particular history of an air mass. This presents a significant challenge when predicting hygroscopic water uptake assuming a constant growth factor of the organic fraction at a given relative humidity, as has usually been done in closure studies.

One has to keep in mind that AMS instruments can only detect particle material that can be volatilized at temperatures up to $600^{\circ} \mathrm{C}$. Ignoring the non-detectable refractory fraction, which includes the widely abundant elemental carbon and sea salt, would result in an under or overprediction of the hygroscopic growth factor in closure studies, respectively (e.g., Gysel et al., 2007).

As proposed by Petters and Kreidenweis (2007), particle hygroscopic growth can be described by a single parameter $\kappa$. The $\kappa$ formulation simplifies the description of particle water uptake, and has successfully been applied in cloud-parcel and global-scale models (Pringle et al., 2010; Spracklen et al., 2008; Reutter et al., 2009). The hygroscopicity parameter $\kappa$ can be derived experimentally from both, Hygroscopicity Tandem Differential Mobility Analyzers (HTDMA) and cloud condensation nucleus counter $(\mathrm{CCNc})$ measurements, however, under very different water activity conditions (Petters and Kreidenweis, 2007). Several studies found a significant discrepancy in the $\kappa$ values derived from both methods. The hygroscopicity parameter derived from HTMDA measurements tend to be lower than those derived from CCNc measurements (Cerully et al., 2011; Irwin et al., 2010). Good et al. (2010) concluded on the basis of their observations that a single parameter is obviously not sufficient to describe the hygroscopic behavior across the sub- and supersaturated regimes.

This work is dedicated to the explanation of observed hygroscopic particle growth and CCN activity as a function of measured chemical particle composition. Atmospheric measurements were recorded during the field experiment under the Hill Cap Cloud Thuringia 2010 (HCCT-2010) project, and involved particle hygroscopic growth measurements under sub- and supersaturated conditions, as well as size-resolved particle chemical composition using an AMS. Based on these data, our study provides a characterization of particle physicochemical properties associated with cloud formation. The hygroscopicity parameter $(\kappa)$ will be used to examine the relationship between the measured subsaturated water uptake, the $\mathrm{CCN}$ activity and the water uptake predicted from the aerosol composition.

\section{Experimental methods}

\subsection{Measurement site}

Physical and chemical characterization of the atmospheric aerosol was performed in the mid-level mountain area in Thuringia, central Germany, from September to October 2010. Three research sites were set up: Schmücke (the summit of the mountain ridge, $937 \mathrm{~m}$ above sea level), Goldlauter (upwind site, $605 \mathrm{~m}$ a.s.l.), and Gehlberg (downwind site, $732 \mathrm{~m}$ a.s.1.). A detailed description of the sampling sites is summarized in Herrmann et al. (2005). In this paper, we will refer to measurements performed at the Goldlauter site. This was the only site at which particle hygroscopicity properties, $\mathrm{CCN}$ characteristics, and aerosol mass spectroscopic measurements were made concurrently. All aerosol instruments were installed in a temperature-controlled container $\left(20^{\circ} \mathrm{C}\right)$. The relative humidity $(\mathrm{RH})$ of the sampled air was kept to below $30 \%$ using an automatic diffusion dryer unit described in Tuch et al. (2009). 


\subsection{Hygroscopic growth measurements}

Particle hygroscopic growth was measured using a HTDMA, which has been described in previous publications in detail (Massling et al., 2007; Massling et al., 2003; Wu et al., 2011). The HTDMA consists of three main parts: (1) a differential mobility analyzer (DMA1) that selects quasimonodisperse particles, and a condensation particle counter (CPC1) that measures the particle number concentration leaving the DMA1 at the selected particle size; (2) an aerosol humidifier conditioning the particles selected by DMA1 to a defined relative humidity; (3) the second DMA (DMA2) coupled with another condensation particle counter (CPC2) to measure the number size distributions of the humidified aerosol.

The hygroscopic growth factor (HGF) determined by the HTDMA is defined as the ratio of the particle mobility diameter, $D_{\mathrm{p}}(\mathrm{RH})$, at a given $\mathrm{RH}$ to its dry diameter, $D_{\mathrm{p} \text { dry }}$ :

$\operatorname{HGF}(\mathrm{RH})=\frac{D_{\mathrm{p}}(\mathrm{RH})}{D_{\mathrm{p} \text { dry }}}$.

The TDMAinv method developed by Gysel et al. (2009) was used to invert the data. Dry scans $(\mathrm{RH}<10 \%)$ are used to calibrate any offset between DMA1 and DMA2 and define the width of the HTDMA's transfer function (Gysel et al., 2009).

The deliquescence point of pure ammonium sulfate particles was measured first to compare with the theoretical one and thus to validate the accuracy and performance of the HTDMA in terms of RH. During the entire field measurements, the hygroscopic growth factor of $100 \mathrm{~nm}$ ammonium sulfate particles were frequently measured at $90 \% \mathrm{RH}$ (twice per three hours) to ensure high quality data.

The measurement uncertainty of the HTDMA depends mainly on the accuracy in $\mathrm{RH}$ within the system but also on a possible size shift between the two DMAs (Massling et al., 2007). As mentioned above, the particle size shift between DMA1 and DMA2 for the entire data set was calibrated using the dry scans (non-humidified particle sizing). The estimated uncertainty in measurements between 30 and $90 \%$ $\mathrm{RH}$ was $\pm 1 \% \mathrm{RH}$. Correspondingly, this uncertainty results in a relative uncertainty of around $2.5 \%$ for GFs of ammonium sulfate particles measured at $90 \%$ RH (Massling et al., 2003).

The residence time of particles at nominal RH $(90 \%)$ before entering into the DMA2 is around $2.5 \mathrm{~s}$ in our system. This residence time may be insufficient for some organic compounds to attain equilibrium state (Chan and Chan, 2005; Peng and Chan, 2001; Duplissy et al., 2009; Sjogren et al., 2007). Therefore, the short residence time could bring additional bias in the measurements for the particles dominated by organics.

\subsection{Particle number size distributions and CCN measurements}

Particle number size distributions $(10-800 \mathrm{~nm})$ were measured by a TROPOS-type mobility particle size spectrometer. A description of this instrument can be found in Wiedensohler et al. (2012). The time resolution was $5 \mathrm{~min}$. The absolute uncertainty of the total particle number concentration of this instrument was determined to be $\pm 5 \%$ in comparison with the particle number concentration measured by standalone CPC (TSI model 3010).

A CCNc (DMT, USA; Roberts and Nenes, 2005) was coupled to a Hauke-type DMA and a CPC (TSI model 3010). Within the DMA monodisperse particles can be selected. The aerosol flow after the DMA is split; one part is sent to a CPC, which counts the total particle number concentration of the aerosol particles. The other part is sent to the $\mathrm{CCNc}$, to count the activated particles at a certain supersaturation. Afterwards, the activated fraction (AF) is determined, which is defined as the ratio of the activated particle number concentration $(\mathrm{CCN})$ to the total particle number concentration $(\mathrm{CN})$ at a particulate supersaturation. This is done for a certain diameter range to gain a full activation curve from zero activated particles up to full activation at an AF of one. This so-called diameter scan is corrected for double charged particles (Deng et al., 2011) and afterwards fitted by a Gaussian error function:

$\mathrm{AF}=\frac{a+b}{2}\left[1+\operatorname{erf}\left(\frac{D-D_{50}}{\sigma \sqrt{2}}\right)\right]$,

where $\mathrm{AF}$ is the activated fraction, erf is the error function, half the maximum value of AF, $D$ is the set diameter and $D_{50}$ is the diameter at AF half of the maximum value, and $\sigma$ is the standard deviation of the cumulative Gaussian distribution function. The center of the error function is interpreted as critical diameter at a fixed supersaturation. A major source of uncertainty in CCN measurement is the derived supersaturation (SS) in $\mathrm{CCN}$ counter. The relative uncertainty for supersaturations $\geq 0.2 \%$ with the $95 \%$ confidence range is $10 \%$. For $\mathrm{SS}<0.2 \%$, the absolute uncertainty is assumed as the same with $\mathrm{SS}=0.2 \%$, i.e., $0.014 \%$. This estimation is made on a basis of the relationship between $\Delta T$ and SS in $\mathrm{CCNc}$ derived from $\mathrm{CCNc}$ calibrations using ammonium sulfate (see the Supplement).

\subsection{Chemical composition measurements}

The Aerodyne High Resolution Time-of-Flight Aerosol Mass Spectrometer (HR-ToF-AMS, here simply referred to as AMS) (DeCarlo et al., 2006) was typically operated with time resolution of $5 \mathrm{~min}$. Due to the $600^{\circ} \mathrm{C}$ surface temperature of the vaporizer, the AMS only analyzes the non-refractory chemical composition of the particles. Soot, crustal material, and sea salt cannot be detected. Therefore, based on the transmission efficiency of 
the aerodynamic lens and the detected compounds, the AMS provides the size-resolved chemical composition of submicrometer non-refractory aerosol fraction (NR-PM1) (Canagaratna et al., 2007). Applying the method developed by Aiken et al. (2008), the high resolution organic particle mass spectra were used to determine the elemental composition and the oxygen to carbon atomic ratio $(\mathrm{O}: \mathrm{C})$.

The black carbon (BC) particle mass concentration was measured by a multi-angle absorption photometer (MAAP, Thermo-scientific Model 5012 (Petzold and Schonlinner, 2004)). The size-resolved elemental carbon (EC) concentration was investigated by laboratory-analysis of Berner impactor samples. The Berner samples were only taken during cloud event periods (cloud events occurred at Schmücke research station). Aluminum impaction substrates were used for particle collection. A fraction of these was analyzed for EC by a two-step thermographic method using a carbon analyzer (C-mat 5500, Ströhlein, Germany). More details of the method are given elsewhere (Gnauk et al., 2008).

Particle density is estimated by comparison of total particle volume concentration calculated from particle number size distribution assuming a spherical particle and bulk particle mass concentration measured with the AMS. The vacuum aerodynamic diameter for AMS measurements was converted to mobility diameter by division of AMS vacuum aerodynamic diameter by the estimated particle density $\left(1600 \mathrm{~kg} \mathrm{~m}^{-3}\right)$.

\section{Methodology}

\subsection{The ZSR mixing rule}

The hygroscopicity parameter, $\kappa$, can be calculated either from the hygroscopic growth factor (HGF) measured by HTDMA, or from the critical diameter derived from $\mathrm{CCNc}$ measurements (Petters and Kreidenweis, 2007):

$\kappa_{\mathrm{HTDMA}}=\left(\mathrm{HGF}^{3}-1\right)\left(\frac{\exp \left(\frac{A}{D_{\mathrm{p} \mathrm{dry}} \cdot \mathrm{HGF}}\right)}{\mathrm{RH}}-1\right)$,

$\kappa_{\mathrm{CCN}}=\frac{4 A^{3}}{27 D_{\mathrm{p} \mathrm{crit}}^{3} \ln ^{2} S_{\mathrm{c}}}$,

$\mathrm{A}=\frac{4 \sigma_{\mathrm{s} / \mathrm{a}} \mathrm{M}_{\mathrm{w}}}{\mathrm{RT} \rho_{\mathrm{w}}}$

where $D_{\mathrm{p} \text { dry }}$ and HGF are the initial dry particle diameter and the hygroscopic growth factor at $90 \% \mathrm{RH}$ measured by HTDMA, respectively. $\sigma_{\mathrm{s} / \mathrm{a}}$ is the droplet surface tension (assumed to be that of pure water, $\sigma_{\mathrm{s} / \mathrm{a}}=0.0728 \mathrm{~N} \mathrm{~m}^{-2}$ ), $M_{\mathrm{w}}$ the molecular weight of water, $\rho_{\mathrm{w}}$ the density of liquid water, $\mathrm{R}$ the universal gas constant, $T$ the absolute temperature, and $D_{\mathrm{p}}$ crit is the critical diameter at which $50 \%$ of the particles were activated at the supersaturation, Sc. According to the uncertainties in CCNc and HTDMA measurements, we roughly estimated that the uncertainty in both $\kappa_{\text {HTDMA }}$ and $\kappa_{\mathrm{CCN}}$ is $10 \%$.

For a given internal mixture, $\kappa$ can also be predicted by a simple mixing rule on the basis of chemical volume fractions $\varepsilon_{i}$ (Petters and Kreidenweis, 2007):

$\kappa_{\mathrm{chem}}=\sum_{i} \varepsilon_{i} \kappa_{i}$.

Here, $\kappa_{i}$ and $\varepsilon_{i}$ are the hygroscopicity parameter and volume fraction for the individual (dry) component in the mixture with $i$ the number of components in the mixture. We derive $\varepsilon_{i}$ from particle chemical composition measured by AMS and MAAP. The detailed description about how to calculate volume fraction is given in section 3.2. In the following discussions, $\kappa_{\mathrm{HTDMA}}, \kappa_{\mathrm{CCN}}$, and $\kappa_{\text {chem }}$ denote respectively the $\kappa$ values derived from HTDMA, $\mathrm{CCNc}$, and AMS plus MAAP measurements.

\subsection{Hygroscopicity-chemical composition closure}

The AMS provides the size-resolved particle mass concentrations of sulfate $\left(\mathrm{SO}_{4}^{2-}\right)$, nitrate $\left(\mathrm{NO}_{3}\right)$, and ammonium $\left(\mathrm{NH}_{4}^{+}\right)$ions as well as the concentration of organic compounds. We used a simplified ion pairing scheme as presented in Gysel et al. (2007) to convert the ion mass concentrations to the mass concentrations of their corresponding inorganic salts as listed in Table 1.

The volume fraction of each species was calculated from the particle mass concentration divided by its density, as given in Table 1. The densities for inorganic salts are well defined. However, BC density may vary depending on its type. The reported values in the literature range from 1000 (Hitzenberger et al., 1999) up to $2000 \mathrm{~kg} \mathrm{~m}^{-3}$ (Gysel et al., 2011). By summarizing the articles published recently (Park et al., 2004; McMurry et al., 2002; Kondo et al., 2011; Kiselev et al., 2010), $1700 \mathrm{~kg} \mathrm{~m}^{-3}$ was selected. The density of organic particle mass fraction was taken as $1400 \mathrm{~kg} \mathrm{~m}^{-3}$ (Gysel et al., 2007; Alfarra et al., 2006; Dinar et al., 2006). The $\kappa_{\text {HTDMA }}$ values for the individual compounds were calculated from the hygroscopic growth factor at $90 \% \mathrm{RH}$ as given in Gysel et al. (2007) using Eq. (3). The hygroscopicity parameter $\kappa$ of the hydrophobic black carbon was assumed to be zero. The $\kappa_{\mathrm{CCN}}$ values of those individual species listed in Table 1 were reported by Petters and Kreidenweis (2007) and Zaveri et al. (2010).

\section{Results and discussions}

\subsection{Particle hygroscopic growth}

Figure 1 shows an overview of growth factor probability density distributions (GF-PDF) during the entire field campaign. The GF-PDF indicates a pronounced size dependence and 


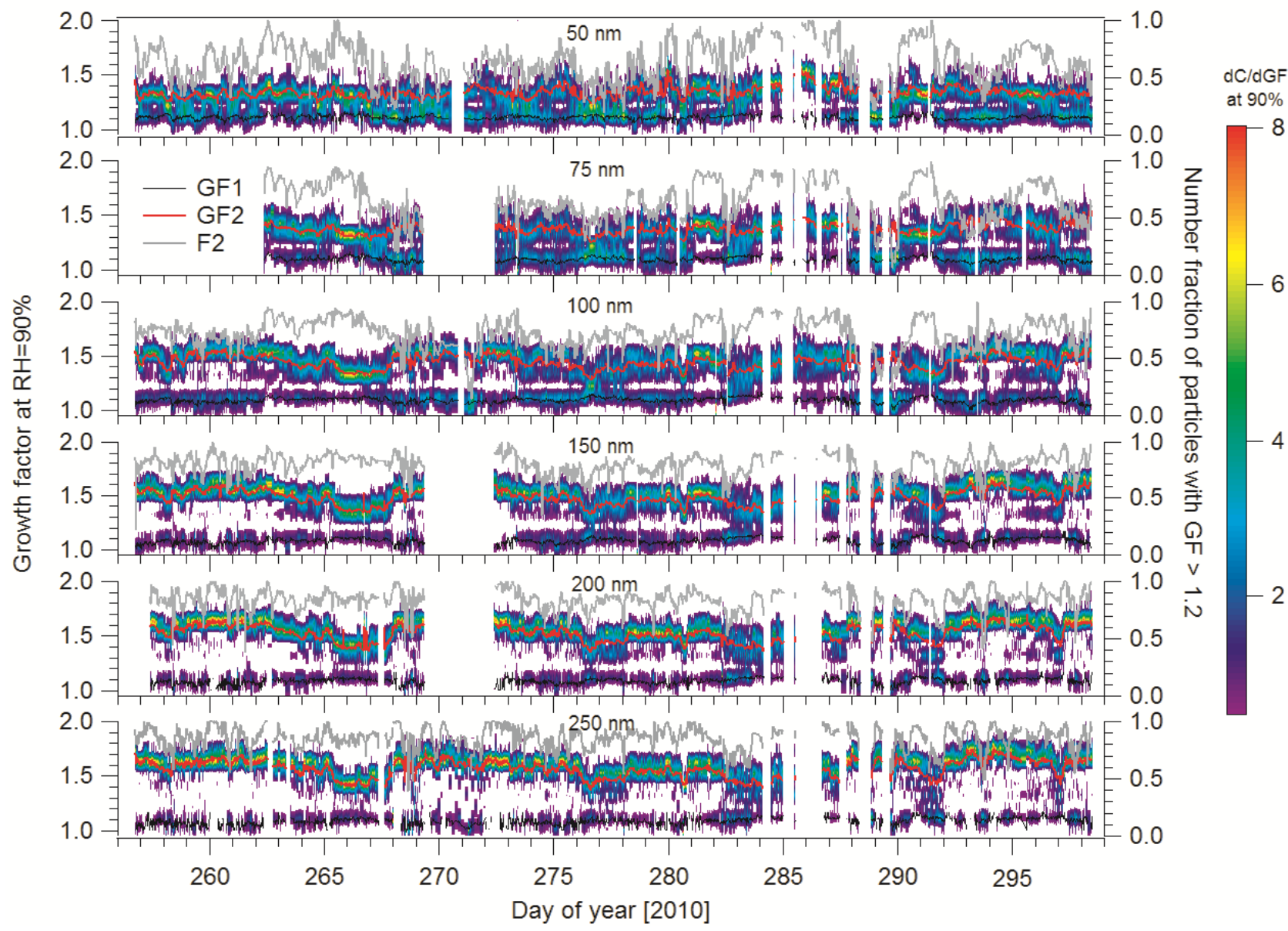

Fig. 1. Size dependence of GF-PDF. GF1 and GF2 represent the mean growth factors of hydrophobic $(\mathrm{GF}<1.2)$ and hydrophilic $(\mathrm{GF}>1.2)$ modes, respectively. F2 means the number fraction of GF2.

temporal variability of particle hygroscopic growth. Generally, GF-PDFs show two distinct modes: hydrophobic mode $($ HGF $<1.2)$ and hydrophilic mode $(\mathrm{HGF}>1.2)$. This indicates that the aerosols are usually externally mixed. However, occasionally the number fraction of hydrophilic mode (F2 in Fig. 1) is close to 1 for particle sizes greater than $100 \mathrm{~nm}$. No matter what particle size is considered, the hydrophilic mode is always more prominent in the GF-PDF. With increasing particle size, the dominance of hydrophilic mode becomes more pronounced. The mean number fractions of the hydrophilic mode for $50,100,150,200,250 \mathrm{~nm}$ particles are respectively $0.64,0.72,0.80,0.84$, and 0.86 . The reason is that larger particles have undergone atmospheric aging processes (coagulation, condensation, chemical reaction, cloud processing) (Pöschl, 2005) for a longer time compared to smaller particles. These aging processes typically enhance the water solubility of particles (Pöschl, 2005; Jimenez et al., 2009).

To allow for a more detailed analysis of HTDMA data, humidograms were measured by varying the RH in the HTDMA between 25 and $90 \%$. The HGF vs. water activity was parameterized by (Dick et al., 2000)

$\mathrm{HGF}=\left[1+\left(a+b a_{\mathrm{w}}+c a_{\mathrm{w}}^{2}\right) \frac{a_{\mathrm{w}}}{1-a_{\mathrm{w}}}\right]^{1 / 3}$.

The humidogram and fitting curves are shown in Fig. 2. The fitting parameters are given in Table 1. A continuous growth without deliquescence behavior was found, indicating the absence of phase change in the RH range from $25-90 \%$. Such phenomenon had been observed for atmospheric aerosols in various locations (e.g., Sjogren et al., 2008; Hennigan et al., 2012). Likewise, laboratory experiments revealed the absence of deliquescence for complex mixtures with an increasing fraction of organic particle compounds (Marcolli and Krieger, 2006). In our observations, the organic compounds are dominating submicrometer particle mass fraction, as can be seen in Fig. 3. This could explain the lack of a phase transition in humidogram.

Figure 3 shows the size dependence of $\kappa_{\text {HTDMA }}$ and the particle mass fractions of the measured chemical composition averaging over the entire sampling period. The median $\kappa_{\text {HTDMA }}$ values of $50,75,100,150,200$, and $250 \mathrm{~nm}$ particles 
Table 1. Gravimetric densities $\rho$ and hygroscopicity parameters $\kappa$ used in this study.

\begin{tabular}{lrrrrr}
\hline Species & $\mathrm{NH}_{4} \mathrm{NO}_{3}$ & $\mathrm{NH}_{4} \mathrm{HSO}_{4}$ & $\left(\mathrm{NH}_{4}\right)_{2} \mathrm{SO}_{4}$ & $\begin{array}{r}\text { Organic } \\
\text { matter }\end{array}$ & $\begin{array}{r}\text { Black } \\
\text { carbon }\end{array}$ \\
\hline$\rho\left[\mathrm{kg} \mathrm{m}^{-3}\right]$ & 1720 & 1780 & 1769 & 1400 & 1700 \\
$\kappa_{\mathrm{HTDMA}}$ & 0.58 & 0.56 & 0.48 & 0.09 & 0 \\
$\kappa_{\mathrm{CCN}}$ & 0.67 & 0.61 & 0.61 & 0.1 & 0 \\
\hline
\end{tabular}

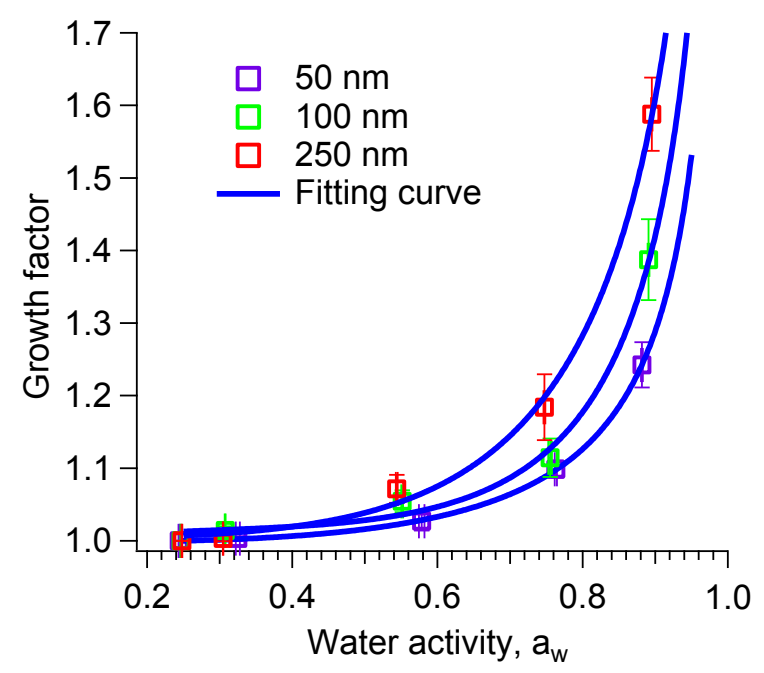

Fig. 2. Experimental dependence of the hygroscopic particle growth factor (HGF) on the water activity. The data represent the total average of HCCT-2010.

are $0.14,0.14,0.17,0.21,0.24$, and 0.28 , respectively. The increasing trend in particle hygroscopic growth is consistent with the decrease in organic particle mass fraction of NR-PM1 with increasing particle size. Typically, the organic compounds have a lower solubility in contrast to inorganic salts, such as ammonium sulfate (Varutbangkul et al., 2006; Virkkula et al., 1999).

\subsection{Hygroscopic closure}

In this section, we compare hygroscopicity parameters that were determined from direct observations (HTDMA) with corresponding values that were calculated on the basis of chemical composition measurements assuming the ZSR mixing rule (cf. Sect. 3). If the values of both approaches agree quantitatively within the range of their uncertainty, closure is achieved.

\subsubsection{Hygroscopic closure using $\mathrm{PM}_{1}$ bulk chemical composition}

In a first step, the submicrometer bulk particle chemical composition was derived from AMS and MAAP measurements. The AMS provides the particle mass fraction of organics and inorganic ions (non-refractory $\mathrm{PM}_{1}$ ), while the MAAP pro-

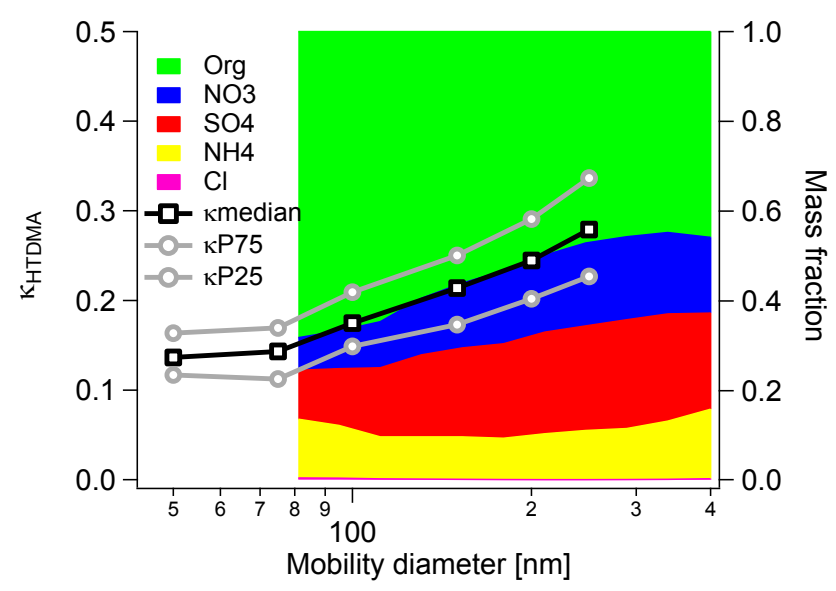

Fig. 3. Comparison between the size-resolved hygroscopicity parameter $\kappa$ and the size-segregated mass fractions of non-refractory compounds during HCCT-2010.

vides a $\mathrm{BC}$ mass concentration (refractory). It needs to be noted that the MAAP determined the BC concentration of $\mathrm{PM}_{10}$. The impactor data showed that $\mathrm{EC}$ in $\mathrm{PM}_{1}$ accounts for more than $90 \%$ of EC in $\mathrm{PM}_{10}$ (see the Supplement). Therefore, we neglected the possible bias caused by difference in measured particle sizes between MAAP and AMS.

Examples for scatter plots of $\kappa_{\text {chem }}$ and $\kappa_{\text {HTDMA }}$ particles are given in Fig. 4, for 250 and $100 \mathrm{~nm}$. A reasonable agreement $\left(r^{2}=0.66\right)$ between predicted and measured $\kappa$ was obtained for $250 \mathrm{~nm}$. For 150 and $200 \mathrm{~nm}$ particles (plots are not shown), the slopes are $1.13\left(r^{2}=0.43\right)$ and $1.31\left(r^{2}=0.65\right)$, respectively. In contrast, almost no correlation was found between $\kappa_{\text {chem }}$ and $\kappa_{\text {HTDMA }}$ for $100 \mathrm{~nm}$ particles. The reason for this disagreement is simple: particle chemical composition is size dependent, as shown in Fig. 3. The submicrometer bulk chemical composition is dominated by particles near the mass median diameter of the mass size distribution around $250-300 \mathrm{~nm}$. The hygroscopic parameter $\kappa$ derived from bulk chemical composition is mainly representative for particle sizes near this median diameter range. This is obviously the case for $250 \mathrm{~nm}$ particles. For $100 \mathrm{~nm}$ particles, which have a much greater fraction of organic compounds than the submicrometer organic mass fraction, such a $\kappa$ comparison is meaningless. Here, the size-resolved chemical mass concentrations are required. 

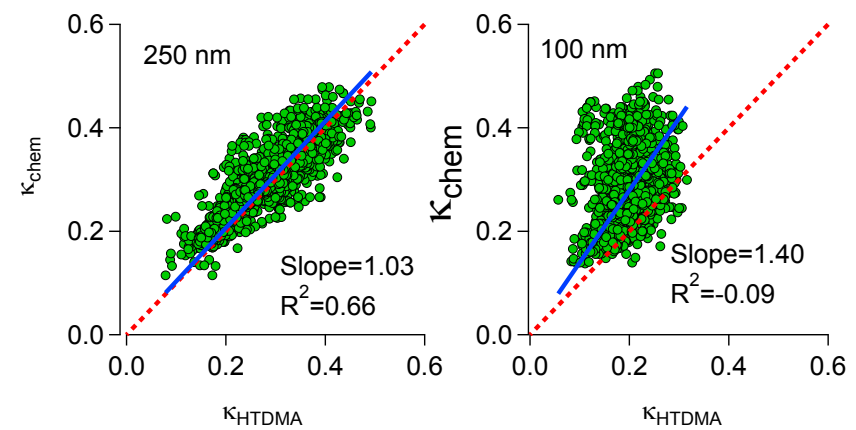

Fig. 4. Correlation between $\kappa_{\text {chem }}$ and $\kappa_{\text {HTDMA }}$ for particles with dry $D_{\mathrm{p}}=100$ and $250 \mathrm{~nm}$, using $\mathrm{PM}_{1}$ bulk chemical composition.

Table 2. Fit parameters of the HGF as a function of the water activity (Fig. 2).

\begin{tabular}{lrrr}
\hline $\begin{array}{l}\text { Particle } \\
\text { diameter }\end{array}$ & $a$ & $b$ & \multicolumn{1}{c}{$c$} \\
\hline $50 \mathrm{~nm}$ & $-4.84 \times 10^{-2}$ & $1.95 \times 10^{-1}$ & $-8.99 \times 10^{-5}$ \\
$100 \mathrm{~nm}$ & $2.28 \times 10^{-1}$ & $-6.04 \times 10^{-1}$ & $6.45 \times 10^{-1}$ \\
$250 \mathrm{~nm}$ & $7.64 \times 10^{-2}$ & $-1.87 \times 10^{-1}$ & $5.48 \times 10^{-1}$ \\
\hline
\end{tabular}

\subsubsection{Hygroscopic closure using size-segregated chemical composition}

In a second step, the size-resolved AMS-derived chemical composition and $\mathrm{BC}$ concentration was used to perform the closure study. To determine the chemical composition of the particles with initial dry diameter investigated with the HTDMA, the mass concentrations for individual species were integrated over the size interval $D_{\mathrm{p} \text { dry }} \pm 20 \mathrm{~nm}$. Considering the considerable statistical uncertainty associated with AMS signals across narrow size ranges, the mass size distribution data derived from AMS were used only if the mass concentration of an individual compound (such as sulfate in $\mathrm{PM}_{1}$ ) was higher than a threshold of $1 \mu \mathrm{g} \mathrm{m}^{-3}$.

The BC concentration within the size range of $D_{\text {dry }} \pm$ $20 \mathrm{~nm}$ was estimated on the basis of the EC mass size distribution. This procedure is outlined in detail in the supplementary material. Briefly, the EC mass fraction within $D_{\text {dry }} \pm 20 \mathrm{~nm}$ was calculated. Afterwards, BC concentration in this size range was estimated by multiplying the total BC concentration and EC mass fraction. Sea salt, mainly $\mathrm{NaCl}$, which cannot be detected by the AMS, is mainly found in coarse mode particles. This also holds for our observations, as the impactor data showed that $\mathrm{Na}^{+}$was mainly detected in the size range between 1.2-3.5 $\mu \mathrm{m}$. Therefore, the prediction bias caused by non-involvement of $\mathrm{NaCl}$ is minor.

The scatter plots of $\kappa_{\text {chem }}$ calculated on the basis of sizeresolved chemical composition against $\kappa_{\text {HTDMA }}$ are shown in Fig. 5a-d. In contrast to the results from bulk chemical composition, the closure is considerably improved for
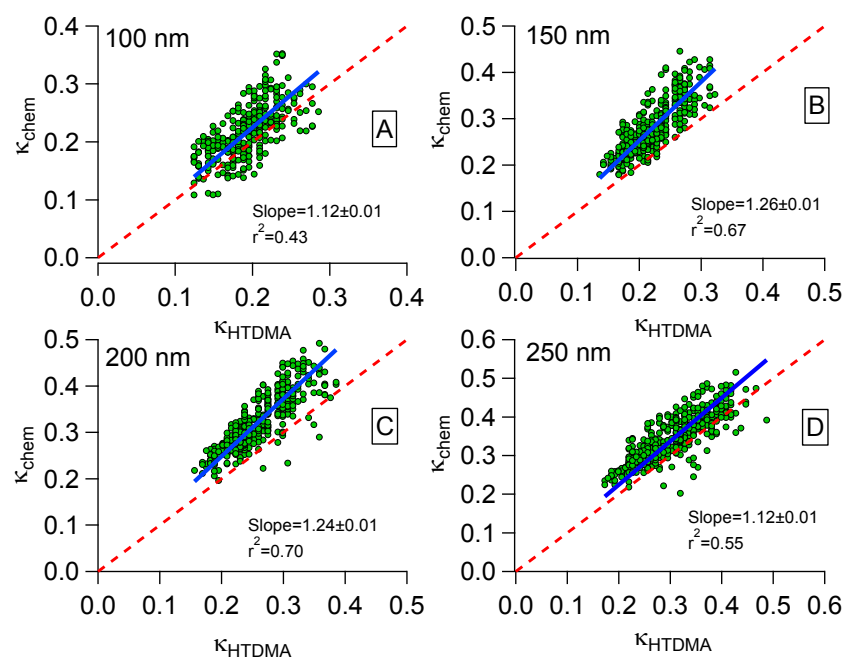

Fig. 5. Correlation between $\kappa_{\text {chem }}$ and $\kappa_{\text {HTDMA }}$ for particles with dry $D_{\mathrm{p}}=100,150,200$, and $250 \mathrm{~nm}$, using size-segregated chemical composition

smaller particles. The fitted slopes for $100\left(r^{2}=0.43\right), 150$ $\left(r^{2}=0.67\right), 200\left(r^{2}=0.70\right)$, and $250 \mathrm{~nm}\left(r^{2}=0.55\right)$ particles are $1.12,1.26,1.24$, and 1.12 , respectively, and are higher than unity. These slopes indicate, despite the reasonable overall agreement, that the prediction on a basis of the ZSR mixing rule overestimates the observed particle hygroscopic growth. Possible explanations are given in detail in the following discussions.

\subsection{Uncertainty of hygroscopic closure}

In this section, we discuss the reasons for the divergence between measured and predicted particle hygroscopicity parameters.

\subsubsection{Loss of $\mathrm{NH}_{4} \mathrm{NO}_{3}$ due to evaporation}

In every measurement of atmospheric aerosols, there is likelihood to lose certain semivolatile particle fractions during sampling, drying, changing temperature, and/or the actual measurement process. Early reports have pointed out the possibility to lose semivolatile aerosol components in differential mobility analyzers (Khlystov et al., 1996). We therefore take a close look at the dependency of the bias observed in the hygroscopicity closure in Sect. 4.2.2 on the most semivolatile aerosol fraction, ammonium nitrate.

Figure 6 shows the difference between $\kappa_{\text {chem }}$ and $\kappa_{\text {HTDMA }}$ $\left(\kappa_{\text {chem }}-\kappa_{\text {HTDMA }}\right)$ vs. the volume fraction of $\mathrm{NH}_{4} \mathrm{NO}_{3}$ $\left(V_{\mathrm{NH}_{4} \mathrm{NO}_{3}}\right)$ for $200 \mathrm{~nm}$ particles. It is obvious that $\kappa_{\text {chem }}{ }^{-}$ $\kappa_{\mathrm{HTDMA}}$ correlates with $V_{\mathrm{NH}_{4} \mathrm{NO}_{3}}$. Such dependency was not observed for other components. This observation is consistent with previous studies that also reported that particle hygroscopic growth measured by HTDMA is lower than that predicted by the AMS/ZSR method when the mass fraction 


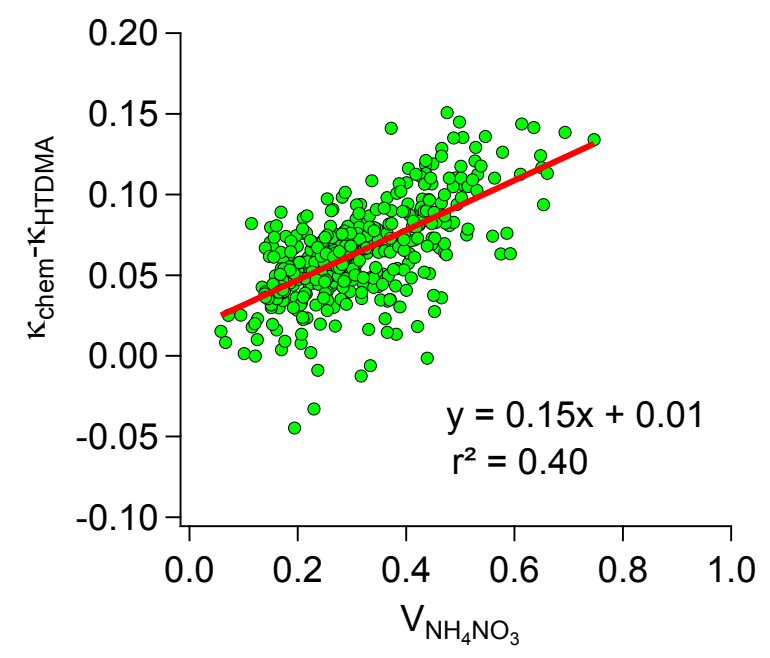

Fig. 6. Difference between $\kappa_{\text {chem }}$ and $\kappa_{\mathrm{HTDMA}}$ as a function of vol-

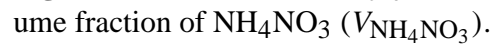

of nitrate was high (Aklilu et al., 2006; Gysel et al., 2007). Gysel et al. (2007) noted that $\mathrm{NH}_{4} \mathrm{NO}_{3}$ is efficiently detected by the AMS, but may evaporate in the HTDMA system (Gysel et al., 2007). The evaporation of $\mathrm{NH}_{4} \mathrm{NO}_{3}$ could take place inside of the DMA. Here, the aerosol sample flow is merged at a ratio of $1: 10$ with the particle-free sheath airflow. Another location might be the humidification section. The evaporation losses of $\mathrm{NH}_{4} \mathrm{NO}_{3}$ have been shown to depend on RH in the humidifier (Mikhailov et al., 2004), and particle residence time in the system (Dassios and Pandis, 1999; Gysel et al., 2007), with the latter one playing the dominant role. Gysel et al. (2007) reported that 50-60\% of the volume of pure $\mathrm{NH}_{4} \mathrm{NO}_{3}$ evaporated for particles in the range of 50 to $100 \mathrm{~nm}$. The residence time in their HTDMA was approximately $60 \mathrm{~s}$ and the RH was set to $90 \%$. In our HTDMA system, the residence time is less than $10 \mathrm{~s}$, and thus, the losses of $\mathrm{NH}_{4} \mathrm{NO}_{3}$ should be smaller. Because the accurate evaporation loss of $\mathrm{NH}_{4} \mathrm{NO}_{3}$ in our instrument is not known, we cannot adopt a correction factor to improve the closure. As shown in Fig. 6, the difference between $\kappa_{\text {chem }}$ and $\kappa_{\mathrm{HTDMA}}$ increased significantly with increasing $V_{\mathrm{NH}_{4} \mathrm{NO}_{3}}$ only when the volume fraction of $V_{\mathrm{NH}_{4} \mathrm{NO}_{3}}$ was larger than $40 \%$. As consequence, we use only data with volume fraction of $\mathrm{NH}_{4} \mathrm{NO}_{3}$ below $40 \%$ to perform the closure study again.

\subsubsection{Unknown hygroscopic growth of organic material}

On average, the organic fractions in $100,150,200$, and $250 \mathrm{~nm}$ particles are $0.58,0.51,0.47$, and 0.43 , respectively. The dominance of organics in non-refractory submicrometer particles indicates that the choice of organic's hygroscopicity parameter $\left(\kappa_{\text {org }}\right)$ in the model will have a significant effect on the predicted $\kappa$ for the entire mixture (cf. Eq. 5). As a first estimate in our closure study we assumed $\kappa_{\text {org }}=0.09$, corre- sponding to a growth factor of 1.2 at $\mathrm{RH}=90 \%$. This value typically represents the hygroscopic growth of more oxidized organic aerosols, which are expected to be present in a continental boundary layer.

As mentioned above, the hygroscopic growth of organic aerosols varies with their oxidation level (Jimenez et al., 2009). We therefore examine a possible relationship between $\kappa_{\text {org }}$ and the oxidation level on the basis of our measurements. If we assume the inorganic fraction is fully explained by the ZSR mixing rule, $\kappa_{\text {org }}$ can be estimated by subtracting $\kappa$ of the inorganic fraction and BC from $\kappa_{\text {HTDMA. }}$ Here, we calculated $\kappa_{\text {org }}$ for $250 \mathrm{~nm}$. Because the uncertainty in the estimation of $\kappa_{\text {org }}$ decreases with increasing organic fraction (Duplissy et al., 2011), only data featuring organic fractions larger than $50 \%$ are used in this calculation. In addition, only data with a $\mathrm{NH}_{4} \mathrm{NO}_{3}$ volume fraction below $10 \%$ are considered in order to reduce the evaporation artifact of $\mathrm{NH}_{4} \mathrm{NO}_{3}$. One should note that both $\kappa \mathrm{s}$ of organics derived from HTDMA (Duplissy et al., 2011; Jimenez et al., 2009; Alfarra et al., 2012) and CCNc (Mei et al., 2013; Chang et al., 2010) measurements were used to correlate with the $\mathrm{O}: \mathrm{C}$ ratio in the literature. Due to the discrepancy between the $\kappa_{\mathrm{HTDMA}}$ and $\kappa_{\mathrm{CCNc}}$ (Good et al., 2010; Irwin et al., 2010) (also see section 4.4), the same dataset may produce a different relationship between $\mathrm{O}: \mathrm{C}$ ratio and $\kappa_{\mathrm{org}}$. In our study, the $\kappa$ derived from HTDMA measurements is taken considering the better closure of HTDMA and AMS measurements (see Sect. 4.4).

Figure 7 shows the $\mathrm{O}: \mathrm{C}$ ratio as a function of $\kappa_{\mathrm{org}}$. A positive correlation was found $\left(r^{2}=0.67\right)$. This agrees with previous studies (e.g., Duplissy et al., 2011; Jimenez et al., 2009), as also displayed in Fig. 7. In most previous studies,

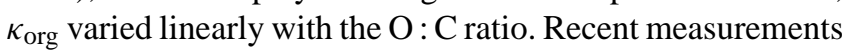
performed by Alfarra et al. (2012) showed that the increasingly oxidized nature of the aerosol appeared to increase the growth factor only marginally, if at all, for $\beta$-caryophyllene secondary organic aerosol. They pointed out these findings might have been influenced by the difference in pre-treatment of the semivolatile-containing particles prior to their measurements.

The mean $\mathrm{O}: \mathrm{C}$ ratio is 0.42 averaged over the entire field campaign. Looking at the results shown in the Fig. 7, $\mathrm{O}: \mathrm{C}=0.42$ corresponds to approximately $\kappa_{\mathrm{org}}=$ 0.05 , which is much smaller than the value 0.09 used in the closure study. This could partly explain the overprediction in the closure study.

In consideration of discussion above, the data with a volume fraction of $\mathrm{NH}_{4} \mathrm{NO}_{3}$ below $40 \%$ and $\kappa_{\text {org }}=0.05$ were used to carry out a second closure study. The respective results are displayed in Fig. 8. The slopes of the linear fits for $100,150,200$, and $250 \mathrm{~nm}$ are respectively $0.99\left(r^{2}=0.47\right)$, $1.13\left(r^{2}=0.61\right), 1.12\left(r^{2}=0.63\right)$, and $1.04\left(r^{2}=0.40\right)$. Compared to the results shown in Fig. 5, the closure was improved. 


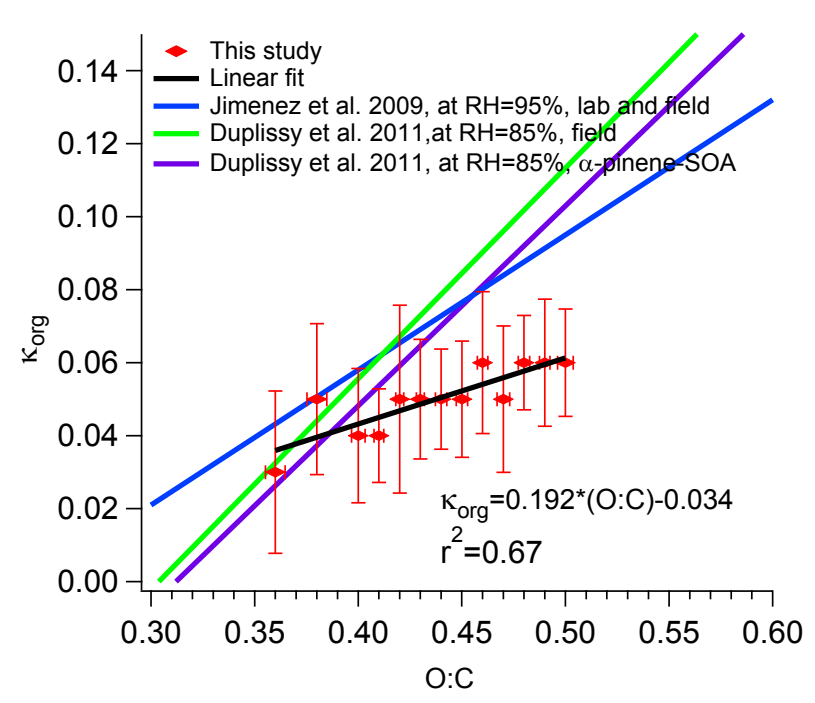

Fig. 7. Correlation between the hygroscopicity parameter for the organic mass fraction, $\kappa_{\mathrm{org}}$, and the oxidation level of the organics based on AMS speciation (O: $\mathrm{C}$ ratio).

Except for the aforementioned reasons, the gas-particle partitioning of semivolatile organic vapors could also produce the potential effect on hygroscopicity closure. A recent study found that allowing the co-equilibration of semivolatile soluble organic compounds results in significantly increasing the amount of soluble material in the particles, thereby substantially increasing the particle hygroscopicity (Topping and McFiggans, 2012). The co-condensation of semivolatile components was not considered when predicting particle hygroscopicity using chemical composition on a basis of the ZSR mixing rule. This could lead to the discrepancy between measured and predicted particle hygroscopicity parameters. Further, such discrepancy will add to the uncertainty in the calculation of $\kappa_{\text {org }}$ and thereby change the relationship between the $\mathrm{O}: \mathrm{C}$ ratio and particle hygroscopicity.

\subsection{Comparison between $\kappa_{\mathrm{HTDMA}}$ and $\kappa_{\mathrm{CCN}}$}

The $\kappa_{\text {HTDMA }}$ was compared with $\kappa_{\mathrm{CCN}}$ to examine the consistency of the hygroscopicity parameter, $\kappa$, derived under sub- and supersaturated conditions. For most of the sampling time, the critical diameters determined with the $\mathrm{CCNc}$ were not exactly the same as the dry diameters $\left(D_{\text {dry }}\right)$ considered by the HTDMA. Hence, data for critical diameters within the range $D_{\text {dry }} \pm 10 \mathrm{~nm}$ were assembled for this comparison. The results are given in Table 3, where it can be seen that for similar sizes $\kappa_{\mathrm{CCN}}$ values are $37 \%$ higher than $\kappa_{\mathrm{HTDMA}}$ values, on average. The upper limit for $\kappa$ derived from HTDMA measurements is reached by assuming the activation of the more hygroscopic mode only during $\mathrm{CCNc}$ measurements. $\kappa$ values were calculated from the hygroscopic growth factor $\left(\kappa_{\text {mode }}\right.$, in Table 3$)$ of hydrophilic mode to compare with $\kappa_{\mathrm{CCN}}$. The $\kappa_{\mathrm{CCN}}$ values are still higher than $\kappa_{\text {mode }}$, while the
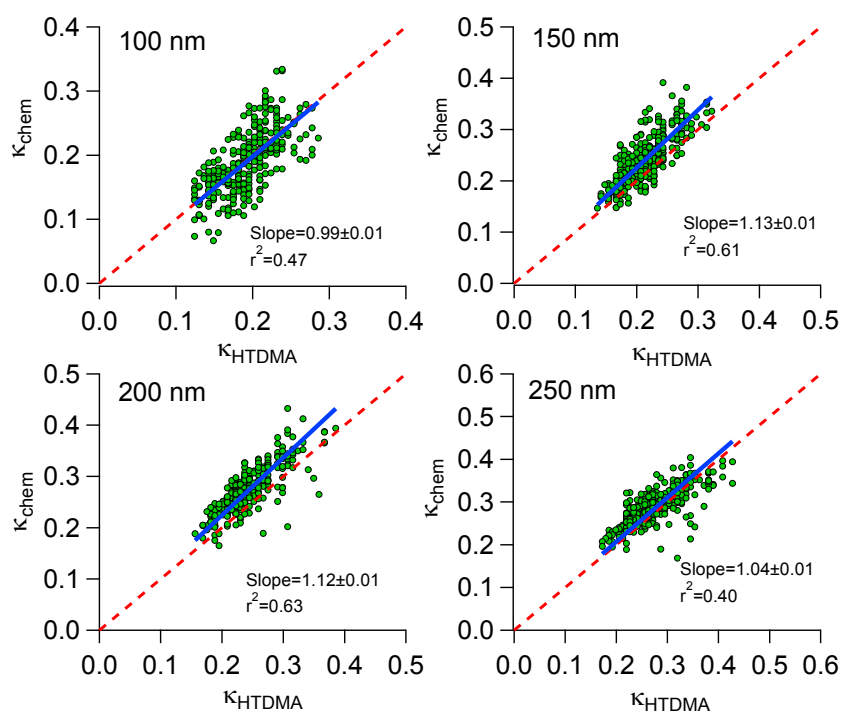

Fig. 8. Correlation between the hygroscopicity parameter $\kappa_{\text {chem }}$ vs. $\kappa_{\mathrm{HTDMA}}, V_{\mathrm{NH}_{4} \mathrm{NO}_{3}}<40 \%$ and $\kappa_{\text {org }}=0.05$.

difference between them decreases around $10 \%$, as can be seen in Table 3.

Such inconsistencies are not unusual, and have been reported in several previous studies (Good et al., 2010; Cerully et al., 2011; Irwin et al., 2010; Petters et al., 2009b; Wex et al., 2009). Possible explanations are non-ideality effects in the solution droplet, surface tension reduction due to surface active substances, and the presence of slightly soluble substances, which dissolve at RHs larger than the one considered in the HTDMA (Wex et al., 2009). As to be seen in e.g., Dieckmann et al. (2013), under atmospheric conditions reductions in surface tension may result in apparently up to $5 \%$ higher $\kappa$ values from CCNc measurements compared to $\kappa$ values from HTDMA measurements. Consequently, reduction of surface tension alone cannot explain the differences observed in the present study, thereby, nonideality effects must play an important role. In addition, a recent study found that the co-condensation of semivolatile soluble organic compounds can substantially decrease the saturation ratio of water vapor required for droplet activation by changing the amount of solutes in the liquid droplets during particle growth (Topping and McFiggans, 2012). This co-condensation process is influenced by particle number concentration, available semivolatile compounds, particle size, and the equilibrium timescale (Topping and McFiggans, 2012). Compared to HTDMA, the circumstance under which particles are detected may be significantly different in CCNc. Therefore, to which extend the co-condensation of semivolatile soluble compounds impacts the ability of particles taking up water is not the same between two systems. This is one of reasons as to why there is a discrepancy between $\kappa_{\mathrm{HTDMA}}$ and $\kappa_{\mathrm{CCN}}$. Due to these effects, $\kappa$ is not necessarily constant and may vary with humidity. As the above 
Table 3. Overview of the HTDMA-derived and CCN-derived hygroscopicity parameters $\kappa$.

\begin{tabular}{lccccccc}
\hline $\begin{array}{c}D_{\mathrm{p}} \\
\mathrm{nm}\end{array}$ & $\begin{array}{c}D_{\text {crit }} \\
\mathrm{nm}\end{array}$ & $\mathrm{SS}$ & $\begin{array}{c}\kappa_{\text {HTDMA }} \\
{[\%]}\end{array}$ & $\kappa_{\text {mode }}$ & $\kappa_{\mathrm{CCN}}$ & $\kappa_{\text {chem,CCN }}$ & $\kappa_{\text {chem, HTDMA }}$ \\
\hline 75 & $73 \pm 5$ & 0.38 & $0.16 \pm 0.04$ & $0.19 \pm 0.03$ & $0.26 \pm 0.05$ & & \\
100 & $104 \pm 6$ & 0.19 & $0.21 \pm 0.03$ & $0.24 \pm 0.03$ & $0.31 \pm 0.06$ & $0.27 \pm 0.05$ & $0.21 \pm 0.05$ \\
150 & $147 \pm 5$ & 0.10 & $0.28 \pm 0.03$ & $0.33 \pm 0.03$ & $0.46 \pm 0.04$ & $0.41 \pm 0.05$ & $0.31 \pm 0.05$ \\
200 & $201 \pm 6$ & 0.07 & $0.23 \pm 0.05$ & $0.27 \pm 0.05$ & $0.37 \pm 0.07$ & $0.36 \pm 0.06$ & $0.23 \pm 0.05$ \\
\hline
\end{tabular}

argument shows, extrapolating from HTDMA data to properties at the point of activation should be done with great care, or for cloud related purposes, these properties should be determined by CCNc measurements directly.

Finally, the $\kappa$ values $\left(\kappa_{\text {chem, }} \mathrm{CCN}\right)$ were calculated using CCNc-derived $\kappa$ values for individual components, given in the third row in Table 1 . As mentioned above and in the results $\left(\kappa_{\text {HTMDA,chem }}\right)$ listed in Table $3, \kappa_{\text {HTDMA }}$ can be well predicted from chemical composition utilizing the ZSR method. When performing a closure study, the considered substances' individual $\kappa$ values are chosen according the humidity applied in the HTDMA. This implies that despite a successful closure between AMS- and HTDMA-derived $\kappa$ values, a bias may exist when comparing HTDMA and AMS to $\mathrm{CCNc}$-derived $\kappa$ values. This is because both, substance individual and mixture $\kappa$ values at $90 \% \mathrm{RH}$, are often significantly lower than those for higher RHs and under supersaturated conditions (Petters and Kreidenweis, 2007). As listed in Table 3 , the differences between $\kappa_{\text {chem, }} \mathrm{CCN}$ and $\kappa_{\mathrm{CCN}}$ are within the data standard deviation, thereby the chemical composition-CCN closure is achieved.

\section{Conclusions}

Simultaneous measurements of particle hygroscopic growth and mixing state, $\mathrm{CCN}$ activity, and size-resolved chemical composition were made during the HCCT-2010 field campaign. Based on these measurements, the hygroscopic parameter $\kappa$, and the ZSR mixing rule was used to examine the relationship between the particle hygroscopic growth, the $\mathrm{CCN}$ activity, and the water uptake predicted from the aerosol composition. The particle hygroscopic growth showed pronounced size dependence. It increased with increasing particle size. During the measurement period, the median $\kappa$ values of $50,75,100,150,200$, and $250 \mathrm{~nm}$ particles derived from the HTDMA measurements are $0.14,0.14$, $0.17,0.21,0.24$, and 0.28 , respectively. No phase transition of particles within $\mathrm{RH}=25-90 \%$ was observed.

It was found that the hygroscopicity-chemistry closure was significantly improved by using size-resolved chemical composition instead of size-averaged chemical composition of the submicrometer aerosol. A positive correlation was found between the discrepancy in predicted and measured hygroscopic parameter $\kappa$ and the volume fraction of
$\mathrm{NH}_{4} \mathrm{NO}_{3}$, indicating that the evaporation of $\mathrm{NH}_{4} \mathrm{NO}_{3}$ could partly explain the difference between predicted and measured particle hygroscopicity. The hygroscopic parameter of the organic fraction, $\kappa_{\text {org }}$, is positively correlated with the $\mathrm{O}: \mathrm{C}$ ratio $\left(\kappa_{\text {org }}=0.19 \times(\mathrm{O}: \mathrm{C})-0.03\right)$. Such correlation is helpful to define the $\kappa_{\text {org }}$ value in closure studies.

Consistency between HTDMA- and CCNc-derived values was not achieved in our study. If only hydrophilic mode in HTDMA measurements is considered, the CCNc-derived $\kappa$ is around $30 \%$ higher than those determined from HTDMA measurements. The surface tension reductions, non-ideality, co-condensation of semivolatile organic compounds, and the partial solubility of constituents or insoluble materials in the particle could explain the discrepancy in $\kappa$ values derived at sub- and supersaturation. Finally, the closure study between $\mathrm{CCNc}$ measured $\left(\kappa_{\mathrm{CCN}}\right)$ and chemical composition $\left(\kappa_{\mathrm{CCN}}\right.$,chem $)$ was performed using $\mathrm{CCNc}$-derived $\kappa$ values for individual components. The results show that the $\kappa_{\mathrm{CCN}}$ can be well predicted using particle size-resolved chemical composition and the ZSR mixing rule.

\section{Supplementary material related to this article is available online at: http://www.atmos-chem-phys.net/13/ 7983/2013/acp-13-7983-2013-supplement.pdf.}

Edited by: G. McFiggans

\section{References}

Aiken, A. C., DeCarlo, P. F., Kroll, J. H., Worsnop, D. R., Huffman, J. A., Docherty, K. S., Ulbrich, I. M., Mohr, C., Kimmel, J. R., Sueper, D., Sun, Y., Zhang, Q., Trimborn, A., Northway, M., Ziemann, P. J., Canagaratna, M. R., Onasch, T. B., Alfarra, M. R., Prevot, A. S. H., Dommen, J., Duplissy, J., Metzger, A., Baltensperger, U., and Jimenez, J. L.: O/c and om/oc ratios of primary, secondary, and ambient organic aerosols with highresolution time-of-flight aerosol mass spectrometry, Environ. Sci. Technol., 42, 4478-4485, doi:10.1021/es703009q, 2008.

Aklilu, Y., Mozurkewich, M., Prenni, A. J., Kreidenweis, S. M., Alfarra, M. R., Allan, J. D., Anlauf, K., Brook, J., Leaitch, W. R., Sharma, S., Boudries, H., and Worsnop, D. R.: Hygroscopicity of particles at two rural, urban influenced sites during pacific 2001: Comparison with estimates of water uptake from particle composition, Atmos. Environ., 40, 2650-2661, doi:10.1016/j.atmosenv.2005.11.063, 2006. 
Alfarra, M. R., Paulsen, D., Gysel, M., Garforth, A. A., Dommen, J., Prévôt, A. S. H., Worsnop, D. R., Baltensperger, U., and Coe, H.: A mass spectrometric study of secondary organic aerosols formed from the photooxidation of anthropogenic and biogenic precursors in a reaction chamber, Atmos. Chem. Phys., 6, 52795293, doi:10.5194/acp-6-5279-2006, 2006.

Alfarra, M. R., Hamilton, J. F., Wyche, K. P., Good, N., Ward, M. W., Carr, T., Barley, M. H., Monks, P. S., Jenkin, M. E., Lewis, A. C., and McFiggans, G. B.: The effect of photochemical ageing and initial precursor concentration on the composition and hygroscopic properties of $\beta$-caryophyllene secondary organic aerosol, Atmos. Chem. Phys., 12, 6417-6436, doi:10.5194/acp12-6417-2012, 2012.

Canagaratna, M. R., Jayne, J. T., Jimenez, J. L., Allan, J. D., Alfarra, M. R., Zhang, Q., Onasch, T. B., Drewnick, F., Coe, H., Middlebrook, A., Delia, A., Williams, L. R., Trimborn, A. M., Northway, M. J., DeCarlo, P. F., Kolb, C. E., Davidovits, P., and Worsnop, D. R.: Chemical and microphysical characterization of ambient aerosols with the aerodyne aerosol mass spectrometer, Mass Spectrom. Rev., 26, 185-222, doi:10.1002/mas.20115, 2007.

Cerully, K. M., Raatikainen, T., Lance, S., Tkacik, D., Tiitta, P., Petäjä, T., Ehn, M., Kulmala, M., Worsnop, D. R., Laaksonen, A., Smith, J. N., and Nenes, A.: Aerosol hygroscopicity and CCN activation kinetics in a boreal forest environment during the 2007 EUCAARI campaign, Atmos. Chem. Phys., 11, 12369-12386, doi:10.5194/acp-11-12369-2011, 2011.

Chan, M. N. and Chan, C. K.: Mass transfer effects in hygroscopic measurements of aerosol particles, Atmos. Chem. Phys., 5, 2703-2712, doi:10.5194/acp-5-2703-2005, 2005.

Chang, R. Y.-W., Slowik, J. G., Shantz, N. C., Vlasenko, A., Liggio, J., Sjostedt, S. J., Leaitch, W. R., and Abbatt, J. P. D.: The hygroscopicity parameter $(\kappa)$ of ambient organic aerosol at a field site subject to biogenic and anthropogenic influences: relationship to degree of aerosol oxidation, Atmos. Chem. Phys., 10, 5047-5064, doi:10.5194/acp-10-5047-2010, 2010.

Cubison, M. J., Ervens, B., Feingold, G., Docherty, K. S., Ulbrich, I. M., Shields, L., Prather, K., Hering, S., and Jimenez, J. L.: The influence of chemical composition and mixing state of Los Angeles urban aerosol on CCN number and cloud properties, Atmos. Chem. Phys., 8, 5649-5667, doi:10.5194/acp-8-5649-2008, 2008.

Dassios, K. G. and Pandis, S. N.: The mass accommodation coefficient of ammonium nitrate aerosol, Atmos. Environ., 33, 2993 3003, doi:10.1016/s1352-2310(99)00079-5, 1999.

DeCarlo, P. F., Kimmel, J. R., Trimborn, A., Northway, M. J., Jayne, J. T., Aiken, A. C., Gonin, M., Fuhrer, K., Horvath, T., Docherty, K. S., Worsnop, D. R., and Jimenez, J. L.: Field-deployable, high-resolution, time-of-flight aerosol mass spectrometer, Anal. Chem., 78, 8281-8289, doi:doi:10.1021/ac061249n, 2006.

Deng, Z. Z., Zhao, C. S., Ma, N., Liu, P. F., Ran, L., Xu, W. Y., Chen, J., Liang, Z., Liang, S., Huang, M. Y., Ma, X. C., Zhang, Q., Quan, J. N., Yan, P., Henning, S., Mildenberger, K., Sommerhage, E., Schäfer, M., Stratmann, F., and Wiedensohler, A.: Size-resolved and bulk activation properties of aerosols in the North China Plain, Atmos. Chem. Phys., 11, 3835-3846, doi:10.5194/acp-11-3835-2011, 2011.

Dick, W. D., Saxena, P., and McMurry, P. H.: Estimation of water uptake by organic compounds in submicron aerosols measured during the southeastern aerosol and visibility study, J. Geophys. Res., 105, 1471-1479, doi:10.1029/1999jd901001, 2000.

Dinar, E., Mentel, T. F., and Rudich, Y.: The density of humic acids and humic like substances (HULIS) from fresh and aged wood burning and pollution aerosol particles, Atmos. Chem. Phys., 6, 5213-5224, doi:10.5194/acp-6-5213-2006, 2006.

Duplissy, J., Gysel, M., Sjogren, S., Meyer, N., Good, N., Kammermann, L., Michaud, V., Weigel, R., Martins dos Santos, S., Gruening, C., Villani, P., Laj, P., Sellegri, K., Metzger, A., McFiggans, G. B., Wehrle, G., Richter, R., Dommen, J., Ristovski, Z., Baltensperger, U., and Weingartner, E.: Intercomparison study of six HTDMAs: results and recommendations, Atmos. Meas. Tech., 2, 363-378, doi:10.5194/amt-2-363-2009, 2009.

Duplissy, J., DeCarlo, P. F., Dommen, J., Alfarra, M. R., Metzger, A., Barmpadimos, I., Prevot, A. S. H., Weingartner, E., Tritscher, T., Gysel, M., Aiken, A. C., Jimenez, J. L., Canagaratna, M. R., Worsnop, D. R., Collins, D. R., Tomlinson, J., and Baltensperger, U.: Relating hygroscopicity and composition of organic aerosol particulate matter, Atmos. Chem. Phys., 11, 11551165, doi:10.5194/acp-11-1155-2011, 2011.

Gnauk, T., Müller, K., van Pinxteren, D., He, L.-Y., Niu, Y., Hu, M., and Herrmann, H.: Size-segregated particulate chemical composition in xinken, pearl river delta, china: Oc/ec and organic compounds, Atmos. Environ., 42, 6296-6309, doi:10.1016/j.atmosenv.2008.05.001, 2008.

Good, N., Topping, D. O., Allan, J. D., Flynn, M., Fuentes, E., Irwin, M., Williams, P. I., Coe, H., and McFiggans, G.: Consistency between parameterisations of aerosol hygroscopicity and CCN activity during the RHaMBLe discovery cruise, Atmos. Chem. Phys., 10, 3189-3203, doi:10.5194/acp-10-3189-2010, 2010.

Gunthe, S. S., King, S. M., Rose, D., Chen, Q., Roldin, P., Farmer, D. K., Jimenez, J. L., Artaxo, P., Andreae, M. O., Martin, S. T., and Pöschl, U.: Cloud condensation nuclei in pristine tropical rainforest air of Amazonia: size-resolved measurements and modeling of atmospheric aerosol composition and CCN activity, Atmos. Chem. Phys., 9, 7551-7575, doi:10.5194/acp-9-75512009, 2009.

Gysel, M., Crosier, J., Topping, D. O., Whitehead, J. D., Bower, K. N., Cubison, M. J., Williams, P. I., Flynn, M. J., McFiggans, G. B., and Coe, H.: Closure study between chemical composition and hygroscopic growth of aerosol particles during TORCH2, Atmos. Chem. Phys., 7, 6131-6144, doi:10.5194/acp-7-61312007, 2007.

Gysel, M., McFiggans, G. B., and Coe, H.: Inversion of tandem differential mobility analyser (tdma) measurements, J. Aerosol Sci., 40, 134-151, doi:10.1016/j.jaerosci.2008.07.013, 2009.

Gysel, M., Laborde, M., Olfert, J. S., Subramanian, R., and Gröhn, A. J.: Effective density of Aquadag and fullerene soot black carbon reference materials used for SP2 calibration, Atmos. Meas. Tech., 4, 2851-2858, doi:10.5194/amt-4-2851-2011, 2011.

Hallquist, M., Wenger, J. C., Baltensperger, U., Rudich, Y., Simpson, D., Claeys, M., Dommen, J., Donahue, N. M., George, C., Goldstein, A. H., Hamilton, J. F., Herrmann, H., Hoffmann, T., Iinuma, Y., Jang, M., Jenkin, M. E., Jimenez, J. L., Kiendler-Scharr, A., Maenhaut, W., McFiggans, G., Mentel, Th. F., Monod, A., Prévôt, A. S. H., Seinfeld, J. H., Surratt, J. D., Szmigielski, R., and Wildt, J.: The formation, properties and impact of secondary organic aerosol: current and emerging issues, 
Atmos. Chem. Phys., 9, 5155-5236, doi:10.5194/acp-9-51552009, 2009.

Hennigan, C. J., Westervelt, D. M., Riipinen, I., Engelhart, G. J., Lee, T., Collett, J. L., Jr., Pandis, S. N., Adams, P. J., and Robinson, A. L.: New particle formation and growth in biomass burning plumes: An important source of cloud condensation nuclei, Geophys. Res. Lett., 39, L09805, doi:10.1029/2012g1050930, 2012.

Herrmann, H., Wolke, R., Müller, K., Brüggemann, E., Gnauk, T., Barzaghi, P., Mertes, S., Lehmann, K., Massling, A., Birmili, W., Wiedensohler, A., Wieprecht, W., Acker, K., Jaeschke, W., Kramberger, H., Svrcina, B., Bächmann, K., Collett Jr, J. L., Galgon, D., Schwirn, K., Nowak, A., van Pinxteren, D., Plewka, A., Chemnitzer, R., Rüd, C., Hofmann, D., Tilgner, A., Diehl, K., Heinold, B., Hinneburg, D., Knoth, O., Sehili, A. M., Simmel, M., Wurzler, S., Majdik, Z., Mauersberger, G., and Müller, F.: Febuko and modmep: Field measurements and modelling of aerosol and cloud multiphase processes, Atmos. Environ., 39, 4169-4183, doi:10.1016/j.atmosenv.2005.02.004, 2005.

Hitzenberger, R., Jennings, S. G., Larson, S. M., Dillner, A., Cachier, H., Galambos, Z., Rouc, A., and Spain, T. G.: Intercomparison of measurement methods for black carbon aerosols, Atmos. Environ., 33, 2823-2833, 1999.

Irwin, M., Good, N., Crosier, J., Choularton, T. W., and McFiggans, G.: Reconciliation of measurements of hygroscopic growth and critical supersaturation of aerosol particles in central Germany, Atmos. Chem. Phys., 10, 11737-11752, doi:10.5194/acp10-11737-2010, 2010.

Irwin, M., Robinson, N., Allan, J. D., Coe, H., and McFiggans, G.: Size-resolved aerosol water uptake and cloud condensation nuclei measurements as measured above a Southeast Asian rainforest during OP3, Atmos. Chem. Phys., 11, 11157-11174, doi:10.5194/acp-11-11157-2011, 2011.

Jimenez, J. L., Canagaratna, M. R., Donahue, N. M., Prevot, A. S. H., Zhang, Q., Kroll, J. H., DeCarlo, P. F., Allan, J. D., Coe, H., Ng, N. L., Aiken, A. C., Docherty, K. S., Ulbrich, I. M., Grieshop, A. P., Robinson, A. L., Duplissy, J., Smith, J. D., Wilson, K. R., Lanz, V. A., Hueglin, C., Sun, Y. L., Tian, J., Laaksonen, A., Raatikainen, T., Rautiainen, J., Vaattovaara, P., Ehn, M., Kulmala, M., Tomlinson, J. M., Collins, D. R., Cubison, M. J., E, Dunlea, J., Huffman, J. A., Onasch, T. B., Alfarra, M. R., Williams, P. I., Bower, K., Kondo, Y., Schneider, J., Drewnick, F., Borrmann, S., Weimer, S., Demerjian, K., Salcedo, D., Cottrell, L., Griffin, R., Takami, A., Miyoshi, T., Hatakeyama, S., Shimono, A., Sun, J. Y., Zhang, Y. M., Dzepina, K., Kimmel, J. R., Sueper, D., Jayne, J. T., Herndon, S. C., Trimborn, A. M., Williams, L. R., Wood, E. C., Middlebrook, A. M., Kolb, C. E., Baltensperger, U., and Worsnop, D. R.: Evolution of organic aerosols in the atmosphere, Science, 326, 1525-1529, doi:10.1126/science.1180353, 2009.

Kanakidou, M., Seinfeld, J. H., Pandis, S. N., Barnes, I., Dentener, F. J., Facchini, M. C., Van Dingenen, R., Ervens, B., Nenes, A., Nielsen, C. J., Swietlicki, E., Putaud, J. P., Balkanski, Y., Fuzzi, S., Horth, J., Moortgat, G. K., Winterhalter, R., Myhre, C. E. L., Tsigaridis, K., Vignati, E., Stephanou, E. G., and Wilson, J.: Organic aerosol and global climate modelling: a review, Atmos. Chem. Phys., 5, 1053-1123, doi:10.5194/acp-5-1053-2005, 2005.
Kiselev, A., Wennrich, C., Stratmann, F., Wex, H., Henning, S., Mentel, T. F., Kiendler-Scharr, A., Schneider, J., Walter, S., and Lieberwirth, I.: Morphological characterization of soot aerosol particles during lacis experiment in november (lexno), J. Geophys. Res.-Atmos., 115, D11204, doi:10.1029/2009jd012635, 2010.

Kondo, Y., Sahu, L., Moteki, N., Khan, F., Takegawa, N., Liu, X., Koike, M., and Miyakawa, T.: Consistency and traceability of black carbon measurements made by laser-induced incandescence, thermal-optical transmittance, and filter-based photo-absorption techniques, Aerosol Sci. Tech., 45, 295-312, doi:10.1080/02786826.2010.533215, 2011.

Lance, S., Nenes, A., Mazzoleni, C., Dubey, M. K., Gates, H., Varutbangkul, V., Rissman, T. A., Murphy, S. M., Sorooshian, A., Flagan, R. C., Seinfeld, J. H., Feingold, G., and Jonsson, H. H.: Cloud condensation nuclei activity, closure, and droplet growth kinetics of houston aerosol during the gulf of mexico atmospheric composition and climate study (gomaccs), J. Geophys. Res., 114, D00F15, doi:10.1029/2008jd011699, 2009.

Marcolli, C., and Krieger, U. K.: Phase changes during hygroscopic cycles of mixed organic/inorganic model systems of tropospheric aerosols, J. Phys. Chem. A, 110, 1881-1893, doi:10.1021/jp0556759, 2006.

Maßling, A., Wiedensohler, A., Busch, B., Neusüß, C., Quinn, P., Bates, T., and Covert, D.: Hygroscopic properties of different aerosol types over the Atlantic and Indian Oceans, Atmos. Chem. Phys., 3, 1377-1397, doi:10.5194/acp-3-1377-2003, 2003.

Massling, A., Leinert, S., Wiedensohler, A., and Covert, D.: Hygroscopic growth of sub-micrometer and one-micrometer aerosol particles measured during ACE-Asia, Atmos. Chem. Phys., 7, 3249-3259, doi:10.5194/acp-7-3249-2007, 2007.

McFiggans, G., Artaxo, P., Baltensperger, U., Coe, H., Facchini, M. C., Feingold, G., Fuzzi, S., Gysel, M., Laaksonen, A., Lohmann, U., Mentel, T. F., Murphy, D. M., O’Dowd, C. D., Snider, J. R., and Weingartner, E.: The effect of physical and chemical aerosol properties on warm cloud droplet activation, Atmos. Chem. Phys., 6, 2593-2649, doi:10.5194/acp-6-2593-2006, 2006.

McMurry, P. H., Wang, X., Park, K., and Ehara, K.: The relationship between mass and mobility for atmospheric particles: A new technique for measuring particle density, Aerosol Sci. Tech., 36, 227-238, doi:10.1080/027868202753504083, 2002.

Medina, J., Nenes, A., Sotiropoulou, R.-E. P., Cottrell, L. D., Ziemba, L. D., Beckman, P. J., and Griffin, R. J.: Cloud condensation nuclei closure during the international consortium for atmospheric research on transport and transformation 2004 campaign: Effects of size-resolved composition, J. Geophys. Res., 112, D10S31, doi:10.1029/2006jd007588, 2007.

Mei, F., Hayes, P. L., Ortega, A., Taylor, J. W., Allan, J. D., Gilman, J., Kuster, W., de Gouw, J., Jimenez, J. L., and Wang, J.: Droplet activation properties of organic aerosols observed at an urban site during calnex-la, J. Geophys. Res.-Atmos., 118, 2903-2917, doi:10.1002/jgrd.50285, 2013.

Mikhailov, E., Vlasenko, S., Niessner, R., and Pöschl, U.: Interaction of aerosol particles composed of protein and saltswith water vapor: hygroscopic growth and microstructural rearrangement, Atmos. Chem. Phys., 4, 323-350, doi:10.5194/acp-4-323-2004, 2004.

Pandis, S. N., Wexler, A. S., and Seinfeld, J. H.: Dynamics of tropospheric aerosols, J. Phys. Chem., 99, 9646-9659, 1995. 
Park, K., Kittelson, D. B., Zachariah, M. R., and McMurry, P. H.: Measurement of inherent material density of nanoparticle agglomerates, J. Nanopart. Res., 6, 267-272, 2004.

Peng, C. G., and Chan, C. K.: The water cycles of water-soluble organic salts of atmospheric importance, Atmos. Environ., 35, 1183-1192, 2001.

Petters, M. D. and Kreidenweis, S. M.: A single parameter representation of hygroscopic growth and cloud condensation nucleus activity, Atmos. Chem. Phys., 7, 1961-1971, doi:10.5194/acp-71961-2007, 2007.

Petters, M. D., Carrico, C. M., Kreidenweis, S. M., Prenni, A. J., DeMott, P. J., Collett, J. L., Jr., and Moosmüller, H.: Cloud condensation nucleation activity of biomass burning aerosol, J. Geophys. Res., 114, D22205, doi:10.1029/2009jd012353, 2009a.

Petters, M. D., Wex, H., Carrico, C. M., Hallbauer, E., Massling, A., McMeeking, G. R., Poulain, L., Wu, Z., Kreidenweis, S. M., and Stratmann, F.: Towards closing the gap between hygroscopic growth and activation for secondary organic aerosol - Part 2: Theoretical approaches, Atmos. Chem. Phys., 9, 3999-4009, doi:10.5194/acp-9-3999-2009, 2009b.

Petzold, A. and Schonlinner, M.: Multi-angle absorption photometry - a new method for the measurement of aerosol light absorption and atmospheric black carbon, J. Aerosol Sci., 35, 421-441, doi:10.1016/j.jaerosci.2003.09.005, 2004.

Pöschl, U.: Atmospheric aerosols: Composition, transformation, climate and health effects, Angew. Chem. Int. Edit., 44, 7520 7541, 2005.

Pringle, K. J., Tost, H., Pozzer, A., Pöschl, U., and Lelieveld, J.: Global distribution of the effective aerosol hygroscopicity parameter for $\mathrm{CCN}$ activation, Atmos. Chem. Phys., 10, 52415255, doi:10.5194/acp-10-5241-2010, 2010.

Reutter, P., Su, H., Trentmann, J., Simmel, M., Rose, D., Gunthe, S. S., Wernli, H., Andreae, M. O., and Pöschl, U.: Aerosol- and updraft-limited regimes of cloud droplet formation: influence of particle number, size and hygroscopicity on the activation of cloud condensation nuclei (CCN), Atmos. Chem. Phys., 9, 70677080, doi:10.5194/acp-9-7067-2009, 2009.

Roberts, G. C. and Nenes, A.: A continuous-flow streamwise thermal-gradient $\mathrm{ccn}$ chamber for atmospheric measurements, Aerosol Sci. Tech., 39, 206-221, doi:10.1080/027868290913988, 2005.

Saxena, P., Hildemann, L. M., McMurry, P. H., and Seinfeld, J. H.: Organics alter hygroscopic behavior of atmospheric particles, J. Geophys. Res., 100, 18755-18770, doi:10.1029/95jd01835, 1995.

Sjogren, S., Gysel, M., Weingartner, E., Baltensperger, U., Cubison, M. J., Coe, H., Zardini, A. A., Marcolli, C., Krieger, U. K., and Peter, T.: Hygroscopic growth and water uptake kinetics of two-phase aerosol particles consisting of ammonium sulfate, adipic and humic acid mixtures, J. Aerosol Sci., 38, 157-171, doi:10.1016/j.jaerosci.2006.11.005, 2007.

Sjogren, S., Gysel, M., Weingartner, E., Alfarra, M. R., Duplissy, J., Cozic, J., Crosier, J., Coe, H., and Baltensperger, U.: Hygroscopicity of the submicrometer aerosol at the high-alpine site Jungfraujoch, $3580 \mathrm{~m}$ a.s.1., Switzerland, Atmos. Chem. Phys., 8, 5715-5729, doi:10.5194/acp-8-5715-2008, 2008.

Sloane, C. S. and Wolff, G. T.: Prediction of ambient light-scattering using a physical model responsive to relative-humidity - validation with measurements from detroit, Atmos. Environ., 19, 669-
680, 1985.

Spracklen, D. V., Carslaw, K. S., Kulmala, M., Kerminen, V.-M., Sihto, S.-L., Riipinen, I., Merikanto, J., Mann, G. W., Chipperfield, M. P., Wiedensohler, A., Birmili, W., and Lihavainen, H.: Contribution of particle formation to global cloud condensation nuclei concentrations, Geophys. Res. Lett., 35, L06808, doi:10.1029/2007g1033038, 2008.

Stokes, R. H. and Robinson, R. A.: Interactions in aqueous nonelectrolyte solutions. I. Solute-solvent equilibria, J. Phys. Chem., 70, 2126-2130, 1966

Swietlicki, E., Zhou, J., Berg, O. H., Martinsson, B. G., Frank, G., Cederfelt, S.-I., Dusek, U., Berner, A., Birmili, W., Wiedensohler, A., Yuskiewicz, B., and Bower, K. N.: A closure study of sub-micrometer aerosol particle hygroscopic behaviour, Atmos. Res., 50, 205-240, doi:10.1016/s0169-8095(98)00105-7, 1999.

Topping, D. O. and McFiggans, G.: Tight coupling of particle size, number and composition in atmospheric cloud droplet activation, Atmos. Chem. Phys., 12, 3253-3260, doi:10.5194/acp-12-32532012, 2012.

Tuch, T. M., Haudek, A., Müller, T., Nowak, A., Wex, H., and Wiedensohler, A.: Design and performance of an automatic regenerating adsorption aerosol dryer for continuous operation at monitoring sites, Atmos. Meas. Tech., 2, 417-422, doi:10.5194/amt-2-417-2009, 2009.

Varutbangkul, V., Brechtel, F. J., Bahreini, R., Ng, N. L., Keywood, M. D., Kroll, J. H., Flagan, R. C., Seinfeld, J. H., Lee, A., and Goldstein, A. H.: Hygroscopicity of secondary organic aerosols formed by oxidation of cycloalkenes, monoterpenes, sesquiterpenes, and related compounds, Atmos. Chem. Phys., 6, 23672388, doi:10.5194/acp-6-2367-2006, 2006.

Virkkula, A., Van Dingenen, R., Raes, F., and Hjorth, J.: Hygroscopic properties of aerosol formed by oxidation of limonene, $\alpha$-pinene, and $\beta$-pinene, J. Geophys. Res., 104, 3569-3579, doi:10.1029/1998jd100017, 1999.

Wex, H., Petters, M. D., Carrico, C. M., Hallbauer, E., Massling, A., McMeeking, G. R., Poulain, L., Wu, Z., Kreidenweis, S. M., and Stratmann, F.: Towards closing the gap between hygroscopic growth and activation for secondary organic aerosol: Part 1 - Evidence from measurements, Atmos. Chem. Phys., 9, 3987-3997, doi:10.5194/acp-9-3987-2009, 2009.

Wiedensohler, A., Birmili, W., Nowak, A., Sonntag, A., Weinhold, K., Merkel, M., Wehner, B., Tuch, T., Pfeifer, S., Fiebig, M., Fjäraa, A. M., Asmi, E., Sellegri, K., Depuy, R., Venzac, H., Villani, P., Laj, P., Aalto, P., Ogren, J. A., Swietlicki, E., Williams, P., Roldin, P., Quincey, P., Hüglin, C., Fierz-Schmidhauser, R., Gysel, M., Weingartner, E., Riccobono, F., Santos, S., Grüning, C., Faloon, K., Beddows, D., Harrison, R., Monahan, C., Jennings, S. G., O’Dowd, C. D., Marinoni, A., Horn, H.-G., Keck, L., Jiang, J., Scheckman, J., McMurry, P. H., Deng, Z., Zhao, C. S., Moerman, M., Henzing, B., de Leeuw, G., Löschau, G., and Bastian, S.: Mobility particle size spectrometers: harmonization of technical standards and data structure to facilitate high quality long-term observations of atmospheric particle number size distributions, Atmos. Meas. Tech., 5, 657-685, doi:10.5194/amt5-657-2012, 2012.

Wu, Z. J., Nowak, A., Poulain, L., Herrmann, H., and Wiedensohler, A.: Hygroscopic behavior of atmospherically relevant water-soluble carboxylic salts and their influence on the water uptake of ammonium sulfate, Atmos. Chem. Phys., 11, 12617- 
12626, doi:10.5194/acp-11-12617-2011, 2011.

Zaveri, R. A., Barnard, J. C., Easter, R. C., Riemer, N., and West, M.: Particle-resolved simulation of aerosol size, composition, mixing state, and the associated optical and cloud condensation nuclei activation properties in an evolving urban plume, J. Geophys. Res., 115, D17210, doi:10.1029/2009jd013616, 2010.

Zdanovskii, B.: Novyi metod rascheta rastvorimostei elektrolitov v mnogokomponentnykh sistema, Zh. Fiz. Khim+, 22, 1478-1485, 1486-1495, 1948.
Zhang, Q., Jimenez, J. L., Canagaratna, M. R., Allan, J., Coe, H., Ulbrich, I., Alfarra, M. R., Takami, A., Middlebrook, A., Sun, Y. L., Dzepina, K., Dunlea, E., Docherty, K., Decarlo, P. F., Salcedo, D., Onasch, T. B., Jayne, J. T., Miyoshi, T., Shimono, A., Hatakeyama, S., Takegawa, N., Kondo, Y., Schneider, J., Drewnick, F., Borrmann, S., Weimer, S., Demerjian, K. L., Williams, P., Bower, K. N., Bahreini, R., Cottrell, L., Griffin, R. J., Rautiainen, J., Sun, J. Y., Zhang, Y. H., and Worsnop, D. R.: Ubiquity and dominance of oxygenated species in organic aerosols in anthropogenically-influenced northern hemisphere midlatitudes, Geophys. Res. Lett., 34, L13801, doi:10.1029/2007GL029979, 2007. 